\title{
Radiant heating rapidly increases litter flammability through impacts on fuel moisture
}

\author{
Jesse K. Kreye ${ }^{1,3^{*}}\left(\mathbb{D}\right.$, Jeffrey M. Kane ${ }^{2}$, J. Morgan Varner ${ }^{3,4}$ and J. Kevin Hiers ${ }^{4}$
}

\begin{abstract}
Background: Litter is the predominant fuel that drives surface fire behavior in most fire-prone forest and woodland ecosystems. The flammability of litter is driven by fuel characteristics, environmental factors, and the interactive effects of the two. Solar radiation can influence litter flammability through its effect on fuel moisture and temperature. The direct influence of radiative heating on flammability, however, is poorly understood and the interactive effects of forest structure, composition, fuels, and micrometeorology may have fine-scale ecological consequences in fire-dependent ecosystems.

Results: In this study, we measured laboratory flammability of two dominant southeastern USA litter fuels—Pinus palustris Mill. and Quercus stellata Wangenh.-and evaluated the interactive effects of fuel moisture and infrared radiation. Heating of litter fuels increased their flammability primarily through enhanced litter drying. Heated litter quickly became more flammable than unheated litter when fuels were undergoing drying after saturation, a result of more rapid moisture loss. Litter mass did not change the effect of heating on drying rates, but heavier fuels burned with greater flammability.
\end{abstract}

Conclusions: Interactions among surface fuels, overstory structure, and solar heating may be important in understanding fine-scale heterogeneity in both fire behavior and effects, with strong implications toward increasing the effectiveness of prescribed burning.

Keywords: fire behavior, Pinus palustris, prescribed fire, Quercus stellata, solar radiation

\section{Resumen}

Antecedentes: El mantillo (o broza) es el combustible predominante que conduce el comportamiento del fuego superficial en la mayoría de los ecosistemas de bosques y arbustales propensos al fuego. La inflamabilidad del mantillo está condicionada por las características del combustible, los factores ambientales y los efectos interactivos entre ambos. La radiación solar puede influenciar la inflamabilidad a través de sus efectos sobre la humedad y temperatura del combustible. La influencia directa del calor radiante en la inflamabilidad, sin embargo, es poco entendida, y los efectos interactivos en la estructura, composición, combustibles, y micro-meteorología pueden tener consecuencias ecológicas a micro-escala en ecosistemas dependientes del fuego.

(Continued on next page)

\footnotetext{
* Correspondence: juk1097@psu.edu

'Department of Ecosystem Science and Management, The Pennsylvania State University, Forest Resources Building, University Park, Pennsylvania 16802, USA

${ }^{3}$ USDA Forest Service, Pacific Wildland Fire Sciences Lab, Pacific Northwest Research Station, 400 N 34th Street, \#201, Seattle, Washington 98103, USA Full list of author information is available at the end of the article
} 
(Continued from previous page)

Resultados: En este estudio, medimos en laboratorio la inflamabilidad de dos mantillos combustibles dominantes en el sud-este de los EEUU_Pinus palustris Mill. y Quercus stellata Wangenh._y evaluamos los efectos interactivos de la humedad de estos combustibles y la radiación infrarroja. El calentamiento del mantillo combustible incrementó su inflamabilidad primariamente a través del aumento en su secado. El mantillo calentado por radiación fue más inflamable que el no calentado cuando los combustibles experimentaron el secado luego de su saturación, resultando de una pérdida más rápida de su humedad. La masa del mantillo no cambió los efectos del calentamiento en la tasa de secado, aunque los combustibles más pesados quemaron con mayor inflamabilidad.

Conclusiones: Las interacciones entre los combustibles de superficie, la estructura del dosel, y el calentamiento solar pueden ser importantes para entender la heterogeneidad a microescala tanto del comportamiento del fuego como de sus efectos, con fuertes implicancias para incrementar la efectividad de las quemas prescritas.

\section{Abbreviations}

ANOVA: ANalysis Of VAriance

FMC: Fuel Moisture Content

PCA: Principal Components Analysis

\section{Introduction}

The role of fire as an ecological process has been well recognized in many fire-dependent ecosystems. The mechanisms by which fire influences plant communities, however, are not fully understood. Interactions among fuels, vegetation, and micrometeorological conditions may influence fire behavior at fine scales and subsequently affect plant diversity (Hiers et al. 2009; Dell et al. 2017). Forest structure and composition affect forest floor shading patterns as well as the composition of surface fuels. The role of these factors in the variability of fire behavior and effects at fine scales may influence vegetation patterns or species diversity in fire-prone landscapes. In many cases, the influx of shade-tolerant, fire-sensitive tree species into formerly pyrogenic landscapes has increased stand densities and altered litter composition with subsequent reductions in potential fire behavior (Kane et al. 2008; Nowacki and Abrams 2008; Mola et al. 2014; Loudermilk et al. 2011; Keyser et al. 2017; Kreye et al. 2018b). An unappreciated mechanism in the variability of fire behavior may be the interactive effects of canopy cover (i.e., shading) and surface fuel characteristics (e.g., composition and mass) on fuel moisture and flammability (Varner et al. 2015, Kreye et al. 2018a, 2018b).

Of all the factors that govern flammability, fuel moisture is of primary importance (Matthews 2014). The dominant physical processes that control fine dead fuel moisture gain are through latent heat effects, adsorption of vapor, condensation, and precipitation, while controls of fuel moisture loss are largely mediated through evaporation (Viney 1991). Fine dead fuels will lose moisture through evaporation at a rate based on the difference between the partial vapor pressure at the near fuel-surface boundary layer and the saturation vapor pressure (i.e., the vapor pressure deficit). The rate of moisture loss is affected by the size of the fuel particles, diffusion properties of fuels, and the density of the fuel bed, but also by microclimatological conditions that influence vapor pressure deficits at the fuel-atmosphere boundary (Byram and Jemison 1943; Van Wagner 1969; Nelson 2001; Kreye et al. 2018a).

Overstory structure influences the amount and duration of forest floor exposure to incoming solar radiation. Surface fuels exposed to direct solar radiation should dry faster than surface fuels sheltered beneath a dense forest canopy. In many cases, field-based experiments have corroborated this trend (e.g., Biddulph and Kellman 1998; Ray et al. 2005; Tanskanen et al. 2006; Kreye et al. 2018a), although other studies have failed to detect persistent differences in fine fuel moisture between treatments that reduce canopy cover (e.g., Faiella and Bailey 2007; Estes et al. 2012). The lack of consistent trends in field observations may be attributed to many factors such as fuel type, fuel composition, fuel depth, and meteorological conditions. For instance, deeper fuel beds may be better insulated from solar radiation, minimizing differences (Simeoni et al. 2011). Also, the influence of fuel depth on radiative drying likely differs based on fuel type. Litter derived from species that have leaves of large surface area (e.g., many angiosperm tree species) and lower fuel bed bulk densities may respond differently to solar radiation than litter from species with smaller leaf surface areas (Kreye et al. 2018a). In humid environments, impacts of solar radiation on surface moisture dynamics may be even more pronounced given expected differences between the fuel boundary layer conditions and the atmosphere when surface fuels are heated (Kreye et al. 2018a). The interactive effects of fuel bed properties and solar radiation on both fuel moisture and subsequent flammability has not been thoroughly examined.

Surface fire behavior is often heterogeneous, a result of variability in fuel bed properties, including fuel type and fuel load, as well as microclimatological factors (e.g. solar radiation, air temperature, humidity, wind). Forest structure and composition affect the spatial variability of fuel bed properties (Banwell et al. 2013; Kreye et al. 
2014; Dell et al. 2017), but also influence below-canopy microclimate (Lee 1978). Fuel bed and microclimate factors likely interact in complex ways to influence forest floor flammability. Fine-scale variability in fuels and subsequent fire behavior has been linked with increased herbaceous diversity in frequently burned ecosystems (Dell et al. 2017). Understanding how fuel bed characteristics and microclimate interact to influence flammability would help to elucidate the drivers of fine-scale heterogeneity of surface fire behavior and their ecological effects.

To evaluate the influence of solar radiation and fuel moisture on flammability, we selected two dominant species from the southeastern USA. Prescribed fire is widely applied in this region and is responsible for circa $70 \%$ of the area prescribed burned annually in the US (Melvin 2015). Much of this burning activity is focused in upland longleaf pine (Pinus palustris Mill.) and oak (Quercus L. spp.) woodlands. In these forests and woodlands, the predominant fuel is pine and oak litter cast from overstory trees. Prior laboratory experiments on these litter types have demonstrated variation in both flammability and moisture dynamics (Kane et al. 2008; Kreye et al. 2013; Kreye et al. 2018b), but have not evaluated differences in flammability over a fuel moisture gradient. Additionally, recent work has clearly demonstrated that solar radiation had different influences on moisture dynamics in pine and oak litter based on lab and field experiments (Kreye et al. 2018a). These findings suggest a potential influence on surface-fire behavior but have not been directly examined. To address these questions more explicitly, our objectives for this study were (1) to evaluate the effects of infrared radiation (mimicking solar radiation) on the flammability of pine and oak litter, separately, via impacts to both fuel heating and moisture dynamics; and (2) to evaluate how quickly litter flammability is increased by exposure to infrared radiation when drying from saturated conditions. The results of our study should better explain the influence of solar heating on forest floor flammability via impacts on fuel moisture and fuel temperature, which will enable managers to promote desired fire behavior and effects that can improve effectiveness in the application of prescribed fire.

\section{Methods}

\section{Litter collection}

We collected longleaf pine and post oak (Quercus stellata Wangenh.) forest floor litter for flammability experiments. All litter $\left(\mathrm{O}_{\mathrm{i}}\right.$ horizon) was recently cast with no visible signs of decomposition. Pine litter was collected from the forest floor of a longleaf pine ecosystem at Tall Timbers Research Station $\left(-84.225^{\circ} \mathrm{W}, 30.657^{\circ} \mathrm{N}\right)$ in northern Florida, USA. Oak litter was collected from an oak- hickory ecosystem at Strawberry Plains Audubon Center $\left(-89.476^{\circ} \mathrm{W}, 34.833^{\circ} \mathrm{N}\right)$ in northern Mississippi, USA. Collected pine and oak litter were bagged and shipped to the Humboldt State Wildland Fire Laboratory (Arcata, California, USA). All experimentation, as described below, was conducted with litter separated by species (i.e., litter never commingled across species).

\section{Litter treatments}

In the lab, collected pine and oak litter was oven dried at $70{ }^{\circ} \mathrm{C}$ and placed in $30 \times 30 \mathrm{~cm}$ litter beds for burning experiments. Litter beds were created to represent a low and a high fuel load scenario for each species. Fourteen $25 \mathrm{~g}$ (oven dry) litter beds were created from each species to represent low fuel loads. Fourteen $50 \mathrm{~g}$ oak litter beds and fourteen $75 \mathrm{~g}$ pine litter beds were created to represent high fuel loads, for a total of 56 litter beds for experimentation. Heavier fuel beds of pine were created for the highload scenario to ensure layering of litter. All created fuel beds were soaked in a water bath for $24 \mathrm{~h}$ (as in Kreye et al. 2018b) until they approximately reached saturation moisture content. Saturated litter beds were subsequently allowed to dry under either ambient laboratory conditions (24 to $28{ }^{\circ} \mathrm{C}$ air temperature, 40 to $50 \%$ relative humidity) or exposed to two $250 \mathrm{~W}$ infrared radiation lamps that emitted circa $600 \mathrm{~W} \mathrm{~m}^{-2}$ at the litter surface (Fig. 1). Infrared radiation flux approximated median noon solar irradiance $\left(572 \mathrm{~W} \mathrm{~m}^{-2}\right)$ recorded at the Tall Timbers Research Station Remote Automated Weather Station between Jan 2013 and Jan 2017; maximum irradiance recorded over that time period was $935 \mathrm{~W} \mathrm{~m}^{-2}$. We calculated irradiance at the litter bed surface by subjecting a block of wood of known emissivity (0.90) to the infrared heating lamps and using the surface temperature of the wood, recorded from a thermal infrared camera, and the Stefan-Boltzmann Equation (Kreye et al. 2018a). Litter temperatures, which reached $50{ }^{\circ} \mathrm{C}$, were similar to those observed during outdoor experiments conducted with similar litter exposed to the sun at Tall Timbers Research Station (Kreye et al. 2018a). Half of the fuel beds (seven of the 14 fuel beds from each fuel load $\times$ species combination) were randomly assigned to infrared exposure. The seven fuel beds within each fuel load $\times$ species $\times$ heating treatment combination were randomly assigned to gravimetric fuel moisture content (FMC) treatments of 0,10 , $20,30,40,50$, and $60 \%$, and allowed to dry under ambient or heated (infrared-exposed) conditions until they reached their specified FMC, and then subsequently burned. Moisture treatments within fuel load $\times$ species $\times$ heating treatment were not replicated because our experiments were designed to capitalize on regression techniques to isolate radiation impacts on flammability via moisture dynamics and increased fuel temperature. 

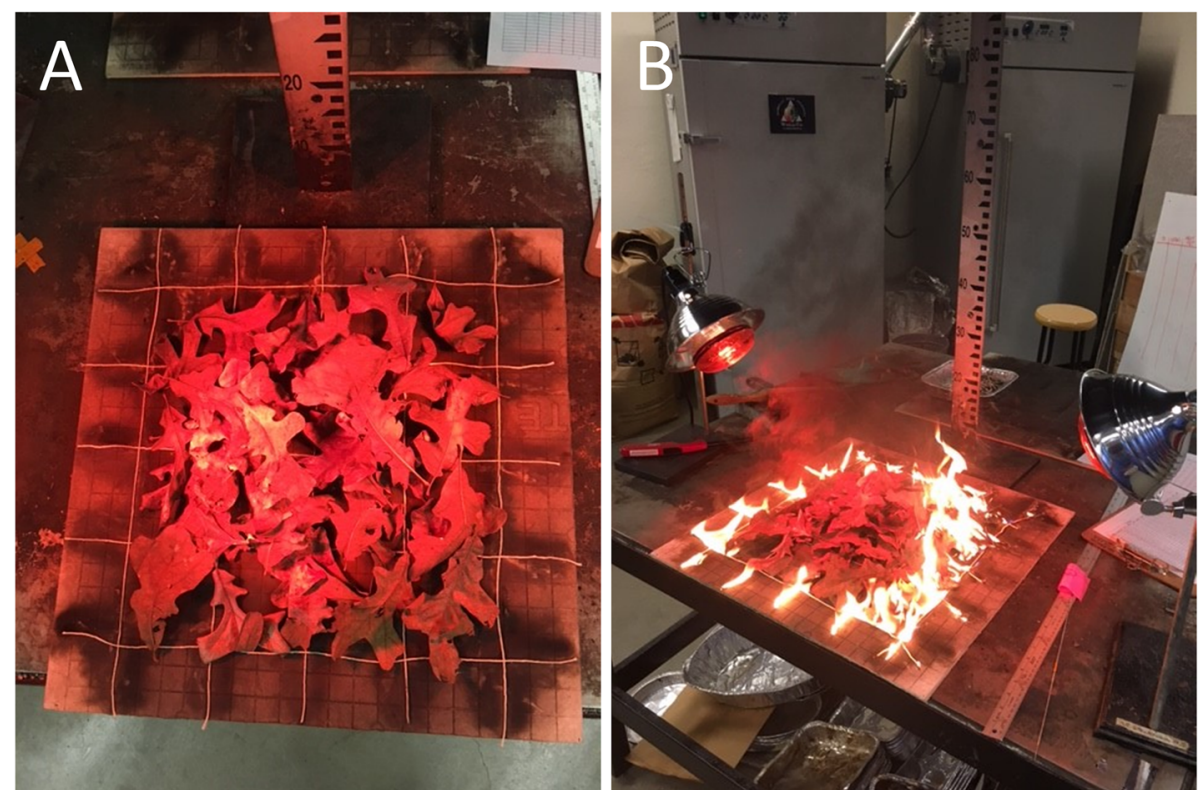

Fig. 1 Post oak (Quercus stellata) litter exposed to infrared heating prior to (A) and during (B) laboratory flammability experiments at Humboldt State University Wildland Fire Laboratory, Arcata, California, USA, in July 2017. Photo by J. Kane

\section{Burning experiments}

Litter beds were individually burned in a laboratory using standard methods (Fonda 2001; Kane et al. 2008; Engber and Varner 2012). Litter beds $(30 \times 30 \mathrm{~cm})$ were transferred directly onto an array of xylene-soaked cotton string laid out in a $40 \times 40 \mathrm{~cm}$ grid on a burn platform (Fig. 1). Litter beds were set atop a fiber cement board to limit heat exchange with the platform surface while burning. To account for potential differences in bulk density across fuel beds, litter depth measurements were taken at four locations (circa $10 \mathrm{~cm}$ from the corners diagonally into the litter bed) prior to ignition and averaged for subsequent analysis. Xylene-soaked strings were then ignited around the perimeter of the array to uniformly ignite the litter beds. Laboratory conditions during burns ranged from 20.0 to $24.8^{\circ} \mathrm{C}(\bar{x}=22.8$, SD $=0.8)$ and 43 to $59 \%$ relative humidity $(\bar{x}=50, \mathrm{SD}=3)$ with no differences across any treatments $(P>0.05)$. For litter beds exposed to infrared heating lamps prior to burning, lamps were also located in the same arrangement on the burn platform prior to transferring litter beds and allowed to continue to heat the litter bed throughout burning experiments (from time of ignition through extinction of smoldering), mimicking solar exposure prior to and during burning. For each burn, we measured maximum flame height $(\mathrm{cm})$, flaming time $(\mathrm{sec})$, smoldering time (sec), and consumption (\%) as in Fonda (2001). Maximum flame height was determined using a graduated ruler located behind the litter beds. Flaming time was recorded from the time of litter ignition to the cessation of flaming. Smoldering time was the duration from the end of flaming to the cessation of visible glowing combustion, observed under darkened conditions.

\section{Data analysis}

Because some flammability metrics are typically correlated, we conducted a principal components analysis (PCA) to combine correlated metrics into PCA factors (which we called flammability factors; Engber and Varner 2012; Kreye et al. 2018b), which were used for subsequent analysis. We selected the number of PCA factors (axes) that explained at least $80 \%$ of the total variation in the dataset and for which factor eigenvalues were $\geq 1$ (Afifi et al. 2004; Abdi and Williams 2010). Principal components analysis factors thus represented flammability indices that were compared across experimental factors.

To evaluate the effect of infrared radiation on flammability through the combined impacts on fuel temperature and moisture dynamics, we used general linear modeling to highlight patterns of increased flammability with drying time across both fuel load and infrared heating treatments. As above, analyses were conducted separately for oak and pine litter beds. Following PCA analysis, we adjusted resulting flammability factor scores to be positive values, with zero being the lowest possible flammability score, assuming litter beds would not burn under saturated conditions. We then correlated flammability factor scores with the drying times required to reach assigned FMC levels using regression analysis without an intercept in the model, again assuming that fuels would not 
ignite at saturation (i.e., zero drying time). We then compared regression slopes across fuel load $x$ infrared heating treatment combinations, with a Tukey multiple comparison test (Miller 1966) using the lstrends function in the lsmeans package (Lenth 2016) in $R$ ( $R$ Development Core Team 2018). This analysis allowed us to evaluate how rapidly flammability increased with duration of drying across fuel load and heating treatments.

To isolate the effect of infrared radiation on flammability beyond its influence on moisture content (i.e., beyond expected increases in drying rates), factor scores were compared across fuel load and heating treatments, for pine and oak separately, using a general linear model analysis of covariance with fuel moisture content as a linear covariate. We tested for both the main effects of fuel load and heating treatment as well as their interactions. This approach allowed us to determine if fuel temperature influenced flammability beyond the effect of infrared heating on decreased fuel moisture content. Assumptions of homoscedasticity and normality of residuals were tested using the Modified-Levene Test (Gastwirth et al. 2009) and Shapiro-Wilk Test (Shapiro and Wilk 1965), respectively.

\section{Results}

Litter flammability metrics of longleaf pine and post oak varied widely across the litter beds burned. Flame heights of the litter fuels ranged from 12 to $145 \mathrm{~cm}$ (Additional file 1). Flaming time and smoldering time ranged from 0.73 to $3.70 \mathrm{~min}$ and 0.13 to $9.75 \mathrm{~min}$, respectively. Litter consumption ranged from 14 to $94 \%$. At the time of burning, litter bed depths differed between fuel load treatments, but not between heating treatments. The $75 \mathrm{~g}$ pine litter beds averaged $4.1 \mathrm{~cm} \pm 0.2 \mathrm{~cm} \mathrm{SE}$ compared to the $25 \mathrm{~g}$ pine litter beds, which averaged $1.9 \mathrm{~cm} \pm 0.2 \mathrm{~cm}$ SE $(P<0.001$, load; $P=0.227$, heating treatment). The $50 \mathrm{~g}$ oak litter averaged $4.3 \mathrm{~cm} \pm 0.1 \mathrm{~cm} \mathrm{SE}$, while the $25 \mathrm{~g}$ oak litter averaged $3.1 \mathrm{~cm} \pm 0.1 \mathrm{~cm}$ SE $(P<0.001$, load; $P=0.069$, heating treatment).

Combining litter flammability metrics using PCA resulted in two factors accounting for $84 \%$ of the variability in the dataset. Factor 1 accounted for 59\% of the variability, with an eigenvalue of 2.37 , and included flame height, smoldering time, and consumption, which were all positively correlated to factor 1 (Table 1) with eigenvectors of $0.59,0.53$, and 0.57 , respectively. Therefore, litter beds with high flammability factor 1 scores burned with tall flames, prolonged smoldering, and high consumption. Factor 2 explained an additional $25 \%$ of the variability, with an eigenvalue of 0.99 , and was primarily composed of flaming time, which was negatively correlated with factor 2 (eigenvector of -0.92). Litter beds that burned with high factor 2 scores flamed more rapidly.

Infrared radiation affected how flammability increased with drying time through the combined effects of heating on both fuel temperature and fuel moisture. Factor 1 (flame height, smoldering time, and consumption) and factor 2 (flaming time) increased with drying time, as expected, but this response was much more rapid with exposure to heating lamps. The comparison of slopes between heating treatment $\times$ litter mass combinations for each species illustrated this effect (Table 2). For $75 \mathrm{~g}$ pine litter beds, the slope of factor 1 versus drying time was five times steeper for the heated treatment compared to the unheated treatment. In $25 \mathrm{~g}$ pine litter beds the slope was 2.5 times greater in heated versus unheated litter, although the differences were marginal $(P=0.09$, Table 2, Fig. 2$)$. Slopes of factor 1 versus drying time in oak litter were three times steeper in heated versus unheated litter beds, regardless of litter mass. Slopes of factor 2 versus drying time were greater for heated pine litter beds compared to unheated pine litter beds, with 4.5 times steeper in 75 g beds and 3.6 times steeper in the lighter $25 \mathrm{~g}$ beds. While this same pattern was found in both the light and heavier oak litter beds, the only difference detected was between the $50 \mathrm{~g}$ heated and the $50 \mathrm{~g}$ unheated litter beds, with three times steeper slopes in heated litter beds (Table 2, Fig. 3).

Effects of infrared heating on flammability were minimal after accounting for impacts on moisture content. For both pine and oak litter, flammability factor 1 (flame

Table 1 Correlation matrix of Principal Component Analysis (PCA) factors and original pine and oak litter flammability metrics measured during laboratory burning experiments at Humboldt State University Wildland Fire Laboratory, Arcata, California, USA, in July 2017. Factor 1 = PCA factor composed primarily of flame height, smolder time, and consumption. Factor $2=$ PCA factor composed primarily of flame time

\begin{tabular}{lccccc}
\hline & Flame height & Flame time & Smolder time & Consumption & Factor 1 \\
\hline Flame height & & & & & \\
Flame time & -0.23 & & & & \\
Smolder time & 0.41 & -0.16 & 0.50 & 0.88 & 0.00 \\
Consumption & 0.85 & -0.03 & 0.82 & 0.28 & \\
Factor 1 & 0.90 & -0.34 & -0.16 & & \\
Factor 2 & 0.22 & 0.92 & & & \\
\hline
\end{tabular}


Table 2 Slopes of flammability score (Principal Component Analysis [PCA] factors 1 and 2) versus drying time for litter mass $x$ infrared heating treatment combinations from pine and oak litter flammability experiments at Humboldt State University Wildland Fire Laboratory, Arcata, California, USA, in July 2017. Factor 1 = PCA factor composed primarily of flame height, smolder time, and consumption. Factor 2 = PCA factor composed primarily of flame time. Shared letters within columns, for species separately, indicate no significant differences between slopes using Tukey multiple comparison test

\begin{tabular}{lll}
\hline Litter $(\mathrm{g})$ & $\begin{array}{l}\text { Factor 1 versus } \\
\text { drying time }\end{array}$ & $\begin{array}{c}\text { Factor 2 versus } \\
\text { drying time }\end{array}$ \\
\cline { 2 - 3 } and treatment & \multicolumn{2}{c}{ Estimated slope } \\
\hline Pine & $0.09^{\mathrm{a}}$ & $0.21^{\mathrm{a}}$ \\
75 unheated & $0.47^{\mathrm{b}}$ & $0.98^{\mathrm{b}}$ \\
75 heated & $0.18^{\mathrm{ac}}$ & $0.20^{\mathrm{a}}$ \\
25 unheated & $0.47^{\mathrm{bc}}$ & $0.72^{\mathrm{b}}$ \\
25 heated & & \\
Oak & $0.17^{\mathrm{a}}$ & $0.10^{\mathrm{a}}$ \\
50 unheated & $0.56^{\mathrm{b}}$ & $0.30^{\mathrm{b}}$ \\
50 heated & $0.23^{\mathrm{a}}$ & $0.14^{\mathrm{ab}}$ \\
25 unheated & $0.70^{\mathrm{b}}$ & $0.30^{\mathrm{ab}}$ \\
25 heated & &
\end{tabular}

height, consumption, and smoldering time) did not differ between heated and unheated treatments $(P=0.917$ and $P=0.175$, respectively), with moisture content being a significant covariate for both species $(P<0.001)$. There was no evidence of differing slopes $(P=0.384$, pine; $P=0.584$, oak) across heating treatment $\times$ litter mass combinations. Litter mass, however, was a significant factor for both pine and oak $(P<0.001)$, with heavier fuel beds burning with higher flame heights, longer smoldering durations, and greater mass consumed (Fig. 4). Interactions between litter mass and heating treatments were not detected for either species $(P>0.05)$. When evaluating differences in flammability factor 2 (flame time), moisture content was not a significant covariate for either pine $(P=0.131)$ or oak $(P=0.850)$ litter beds (Fig. 5). Using a two-way analysis of variance (ANOVA) without moisture content as a covariate, factor 2 differed between the heavier and lighter litter beds for both species $(P<$ 0.001 , pine; $P=0.003$, oak), but was not different between the heated and unheated treatments $(P=0.951$, pine; $P=$ 0.807 , oak). Heavier litter beds flamed more rapidly than did lighter litter beds for both species. There were no interactions between litter mass and infrared heating treatment for either species $(\mathrm{P}>0.05)$.

\section{Discussion}

In this study, we examined the role of infrared heating on the flammability of pine and oak litter, two dominant fuels in the southeastern US. Increases in flammability resulting from exposure to infrared radiation suggest an important role of solar heating of forest floor fuels in surface fire behavior. Although solar impacts are often assumed to influence factors related to fire behavior (Bradshaw et al. 1983), the more rapid response of litter flammability to drying under infrared heating highlights how quickly flammability increases when fine fuels are drying under exposure to infrared radiation. Furthermore, results from this study demonstrate more clearly how infrared heating influences the flammability of fine fuels.

Infrared radiation increased flammability of both pine and oak litter, but effects primarily occurred via impacts on moisture content. Litter exposed to infrared lamps dried quickly and became more flammable than unheated litter. Fuels at higher temperatures
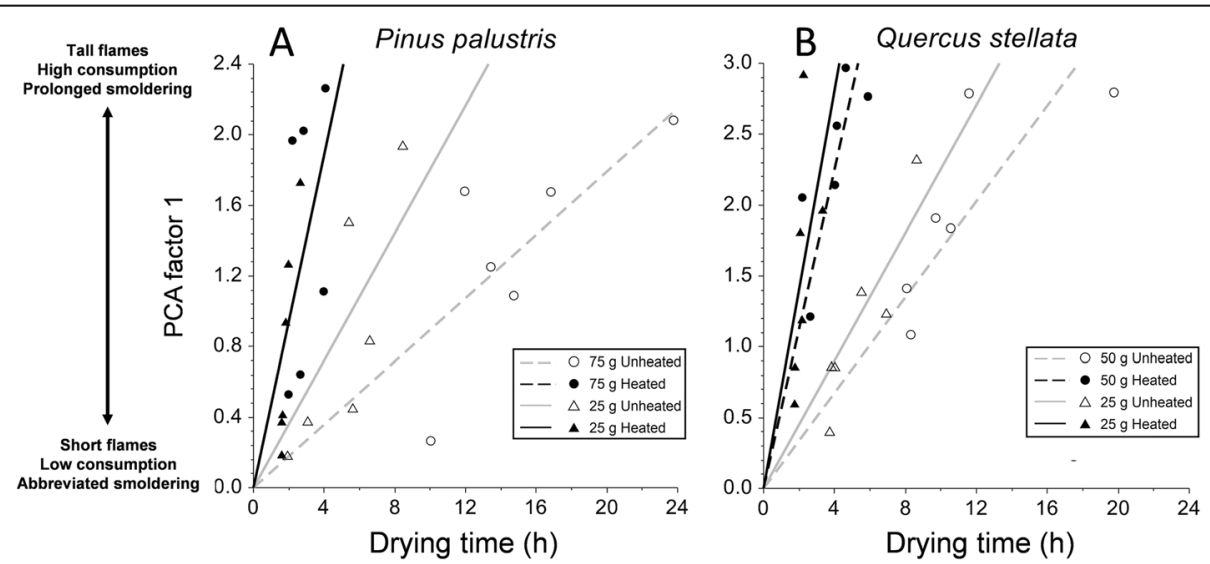

Fig. 2 Flammability factor 1 scores (flame height, consumption, and smoldering time combined via Principal Components Analysis) as a function of drying time during laboratory burning at Humboldt State University Wildland Fire Laboratory, Arcata, California, USA, in July 2017 , of (A) 25 and $75 \mathrm{~g}$ of longleaf pine (Pinus palustris) litter and (B) 25 and $50 \mathrm{~g}$ of post oak (Quercus stellata) litter. Note that Pinus palustris $25 \mathrm{~g}$ and $50 \mathrm{~g}$ heated treatments are aligned along the same slope 

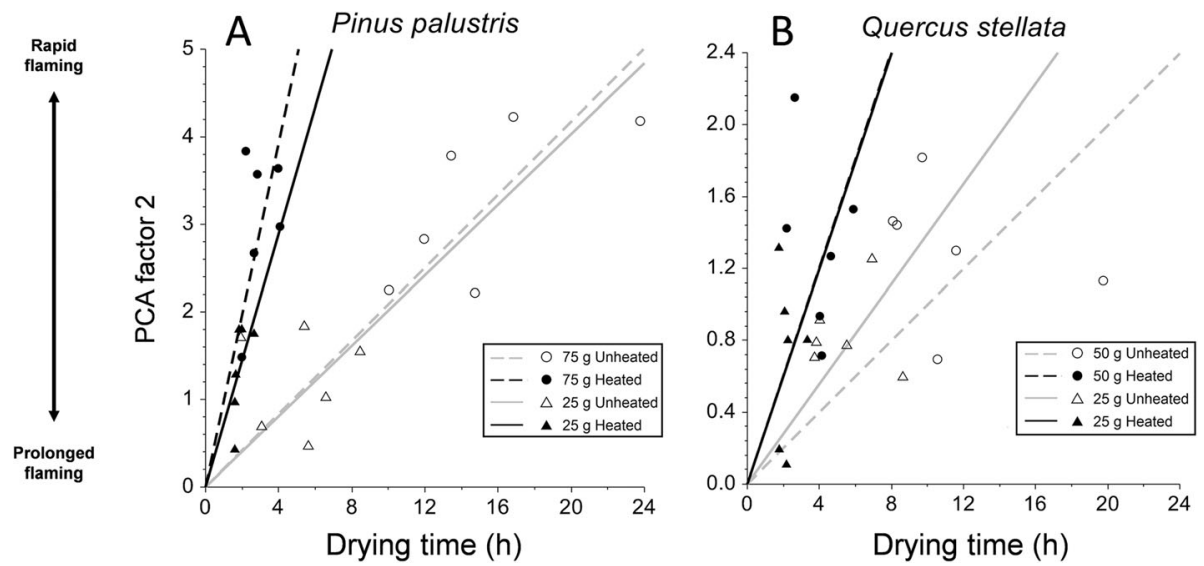

Fig. 3 Flammability factor 2 scores (flaming time) as a function of drying time during laboratory burning at Humboldt State University Wildland Fire Laboratory, Arcata, California, USA, in July 2017, of (A) 25 and $75 \mathrm{~g}$ of longleaf pine (Pinus palustris) litter and (B) 25 and $50 \mathrm{~g}$ of post oak (Quercus stellata) litter. Note that Quercus stellata 25 and $75 \mathrm{~g}$ heated treatments are aligned along the same slope

require less energy input to reach combustion temperatures ( $\operatorname{circa} 300$ to $350{ }^{\circ} \mathrm{C}$ ), but the reduction of energy required for combustion due to radiationinduced decreases in moisture content is a substantially greater impact. The specific heat of water is higher than forest fuel material and the energy requirements associated with latent processes (e.g., latent heat of vaporization) are considerable (Rothermel 1972). Effects of solar heating on moisture dynamics in forest floor litter has been documented (Byram and Jemison 1943; Countryman 1977; Kreye et al. 2018a), and results here confirmed the importance of these effects on flammability.

Effects of radiative heating on litter moisture dynamics may reveal the importance of boundary layer conditions influencing water movement. While ambient air temperature and relative humidity are often used to predict surface fuel moisture (Bradshaw et al. 1983), the importance of vapor pressure deficit at the near fuelsurface boundary layer is critical given the impacts of radiative heating on the temperature of the fuel surface (Byram and Jemison 1943; Van Wagner 1969; Kreye et al. 2018a). Temperatures at the litter bed surface in this study reached as high as $50{ }^{\circ} \mathrm{C}$, up to $30{ }^{\circ} \mathrm{C}$ higher than ambient conditions, similar to outdoor studies conducted with fuels from the same tree species (Kreye et al. 2018a). The concomitant decrease in relative humidity and increased vapor pressure deficit at the fuel-atmosphere boundary layer enhances surface evaporation and subsequent desorption of moisture from within the fuel. A better understanding of fuel-atmospheric dynamics at the near
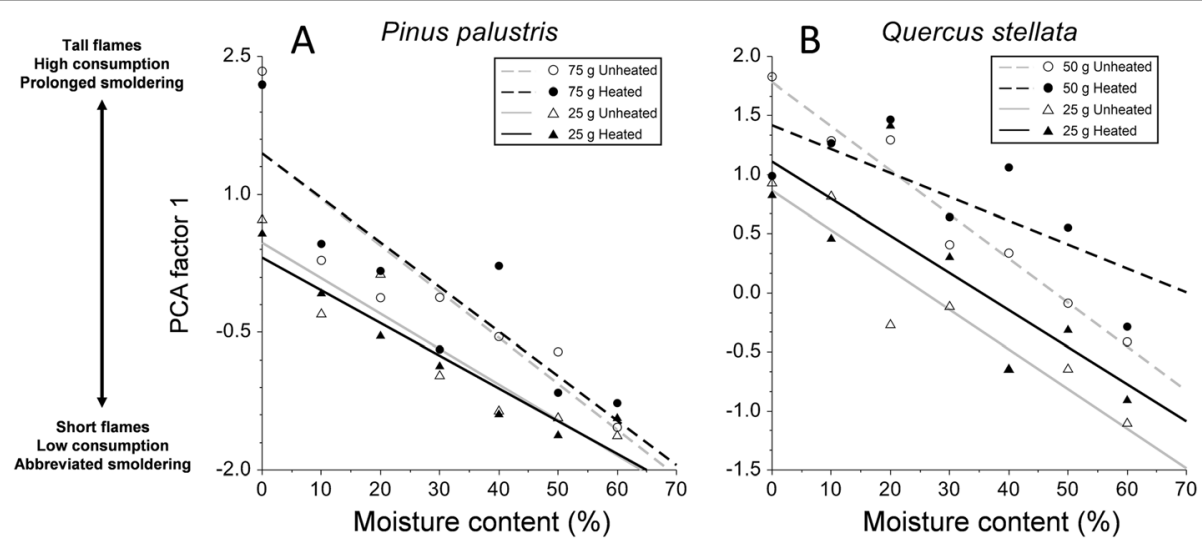

Fig. 4 Flammability factor 1 scores (flame height, consumption, and smoldering time combined via Principal Components Analysis) as a function of moisture content during laboratory burning at Humboldt State University Wildland Fire Laboratory, Arcata, California, USA, in July 2017, of (A) 25 and $75 \mathrm{~g}$ of longleaf pine (Pinus palustris) litter and (B) 25 and $50 \mathrm{~g}$ of post oak (Quercus stellata) litter. Note that Pinus palustris $75 \mathrm{~g}$ heated and unheated treatments are aligned along the same slope 

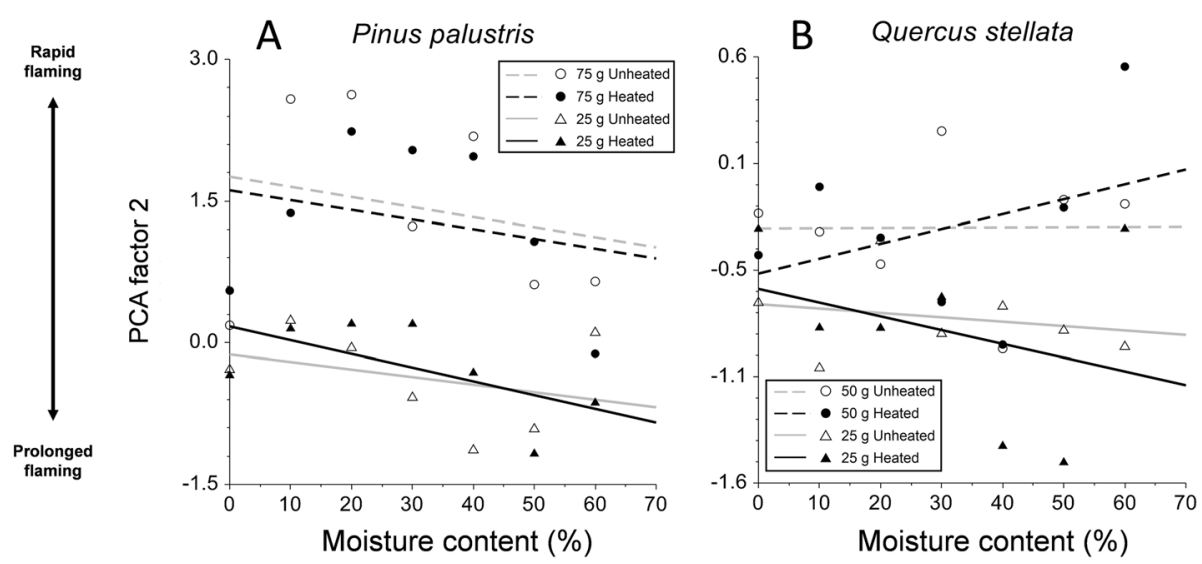

Fig. 5 Flammability factor 2 scores (flame time) as a function of moisture content during laboratory burning at Humboldt State University Wildland Fire Laboratory, Arcata, California, USA, in July 2017, of (A) 25 and $75 \mathrm{~g}$ of longleaf pine (Pinus palustris) litter and (B) 25 and $50 \mathrm{~g}$ of post oak (Quercus stellata) litter

fuel-surface boundary layer will be important for more precisely predicting solar heating influences on moisture dynamics and fire behavior in forest floor fuels.

Differences in flammability observed between heavier and lighter litter beds in this study highlight the role of fuel bed properties in fire behavior and fuel-atmospheric dynamics. When controlling for moisture content, heavier litter beds were more flammable than their lighter counterparts within each species, not surprising given that they were composed of greater fuel, (i.e., more potential energy for combustion). When evaluating flammability over drying time, however, heavier litter beds trended toward lower flammability compared to lighter beds unexposed to infrared heating. Given that differences were not observed when controlling for moisture content, this effect is likely due to slower moisture loss in the heavier fuels (Kreye et al. 2012). Flammability increased with drying time much more rapidly in heated versus unheated litter beds, and slopes between flammability and drying time were consistent between litter masses. The effects of solar heating may overcome fuel bed influences on moisture dynamics in these fine-litter fuels.

Since litter is often spatially patchy in many ecosystems (Banwell and Varner 2014; Kreye et al. 2014), this finding of differential flammability suggests a complex canopy and surface fuel interaction to explain heterogeneous fire behavior (Hiers et al. 2009). Litter composition and loading, a reflection of the overstory, influences both moisture dynamics (Banwell et al. 2013; Kreye et al. 2013, 2018b) and flammability (Varner et al. 2015, Kreye et al. 2018b). Spatial variability of surface fuels and overstory structure along with fine-scale changes in meteorological conditions may play significant roles in fine-scale heterogeneity of surface-fire behavior and the potential effects it has on understory patterns of biodiversity
(Mitchell et al. 2009; Dell et al. 2017). While it is understood that herbaceous diversity in many fire-dependent ecosystems (e.g., longleaf pine woodlands and savannas) depend on frequent burning, there is no clear understanding of the mechanisms involved. Complex interactions between overstory structure and composition, micrometeorology, surface fuels, and fire behavior may be important in understanding fine-scale patterns of herbaceous flora in these highly diverse fire-dependent ecosystems.

\section{Conclusions and management implications}

Our findings that radiative heating can result in the more rapid drying of litter and increased flammability hold potential insights to assist prescribed fire practitioners. Assuming that our radiative heating trials are fair approximations of solar radiation, we expect that solar radiation would portend a greater influence on the spatial patchiness of fuel moisture conditions and, thus, fire behavior and effects, that managers could incorporate into their planning to better meet prescribed fire objectives. This capacity would be strengthened if there were models available to incorporate the fine-scale effect of solar radiation on fuel moisture. While studies in drier regions have not found differences in surface fuel moisture with reductions in canopy cover (Faiella and Bailey 2007; Estes et al. 2012), there is some evidence that these types of treatments in more humid climates may have a more substantial influence (Kreye et al. 2018a). Thus, conducting prescribed fire treatments following canopy reduction treatments may reduce fuel moisture to increase fire behavior and fuel consumption in some areas. While more research is needed, this line of research could provide essential information to increase the effectiveness of prescribed fire in many regions. 


\section{Supplementary information}

Supplementary information accompanies this paper at https://doi.org/10. 1186/s42408-020-0067-3.

Additional file 1: Flammability metrics measured during laboratory burning at Humboldt State University Wildland Fire Laboratory, Arcata, California, USA, in July 2017, of pine (Pinus palustris) and oak (Quercus stellata) litter beds that were either heated or unheated by infrared heating lamps. Factors loadings of fire behavior metrics from Principal Components Analysis (PCA) are presented along with factor 1 means (grand mean, factor means, and marginal means) compared across heating treatments and low and high fuel loads using general linear model analysis of covariance with moisture content as a covariate. Factor 1 = PCA factor composed primarily of flame height, smolder time, and consumption. Factor 2 = PCA factor composed primarily of flame time.

\section{Acknowledgements}

Funding was provided by the National Fire Plan. We thank G. Hamby and B. McNamara for providing lab assistance. We appreciate K. Yedinak for reviewing an earlier version of the manuscript.

\section{Available data and materials}

See Additional file 1 for flammability metrics data.

\section{Authors' contributions}

All authors contributed to study design and manuscript preparation. JMK and JKK implemented experiments and analyzed data. All authors read and approved the final manuscript.

\section{Funding}

US National Fire Plan provided funds to design and conduct experiments.

\section{Ethics approval and consent to participate}

Not applicable.

\section{Consent for publication}

Not applicable.

\section{Competing interests}

The authors declare that they have no financial or non-financial competing interests.

\section{Author details}

'Department of Ecosystem Science and Management, The Pennsylvania State University, Forest Resources Building, University Park, Pennsylvania 16802, USA. ²Department of Forestry and Wildland Resources, Humboldt State University, 1 Harpst Street, Arcata, California 95521, USA. ${ }^{3}$ USDA Forest Service, Pacific Wildland Fire Sciences Lab, Pacific Northwest Research Station, 400 N 34th Street, \#201, Seattle, Washington 98103, USA. ${ }^{4}$ Tall Timbers Research Station, 13093 Henry Beadel Road, Tallahassee, Florida 32312, USA.

Received: 28 March 2019 Accepted: 30 January 2020

Published online: 05 March 2020

\section{References}

Abdi, H., and L.J. Williams. 2010. Principal component analysis. Wiley Interdisciplinary Reviews: Computational Statistics 2: 433-459 https://doi.org/10. 1002/wics.101.

Afifi, A., V.A. Clark, and S. May. 2004. Computer-Aided Multivariate Analysis. 4th ed. Boca Raton, FL: Chapman \& Hall/CRC Press.

Banwell, E.M., J.M. Varner, E.E. Knapp, and R.W. Van Kirk. 2013. Spatial, seasonal, and diel forest floor moisture dynamics in Jeffrey pine-white fir forests of the Lake Tahoe Basin, USA. Forest Ecology and Management 305: 11-20 https://doi.org/10.1016/j.foreco.2013.05.005.

Banwell, E.M., and J.M. Varner. 2014. Structure and composition of forest floor fuels in long-unburned Jeffrey pine-white fir forests of the Lake Tahoe Basin, USA. International Journal of Wildland Fire 23: 363-72.
Biddulph, J., and M. Kellman. 1998. Fuels and fire at savanna-gallery forest boundaries in southeastern Venezuela. Journal of Tropical Ecology 14: 445-461 https://doi.org/10.1017/S0266467498000339.

Bradshaw, L.S., Deeming, J.E., Burgan, R.E., and J.D. Cohen.1983. The 1978 National Fire Danger Rating System: technical documentation. USDA Forest Service, Intermountain Forest and Range Experiment Station General Technical Report INT-GTR-169. (Ogden, UT)

Byram, G.M., and G.M. Jemison. 1943. Solar radiation and forest fuel moisture. Journal of Agricultural Research 67: 149-176.

Countryman CM (1977) Radiation effects on moisture variation in ponderosa pine litter. USDA Forest Service, Pacific Southwest Forest and Range Experiment Station Research Paper PSW-126 (Berkeley, CA)

Dell, J.E., L.A. Richards, J.J. O'Brien, E.L. Loudermilk, A.T. Hudak, S.M. Pokswinski, B.C. Bright, and J.K. Hiers. 2017. Overstory-derived surface fuels mediate plant species diversity in frequently burned longleaf pine forests. Ecosphere 8: e01964 https://doi.org/10.1002/ecs2.1964.

Engber, E.A., and J.M. Varner. 2012. Patterns of flammability of the California oaks: the role of leaf traits. Canadian Journal of Forest Research 42: 1965-1975 https://doi.org/10.1139/×2012-138.

Estes, B.L., E.E. Knapp, C.N. Skinner, and F.C.C. Uzoh. 2012. Seasonal variation in surface fuel moisture between unthinned and thinned mixed conifer forest, northern California, USA. International Journal of Wildland Fire 21: 428-435 https://doi.org/10.1071/WF11056.

Faiella, S.M., and J.D. Bailey. 2007. Fluctuations in fuel moisture across restoration treatments in semi-arid ponderosa pine forests of northern Arizona, USA International Journal of Wildland Fire 16: 119-127 https://doi.org/10.1071/ WF06018.

Fonda, R.W. 2001. Burning characteristics of needles from eight pine species. Forest Science 47: 390-396

Gastwirth, J.L., Y.R. Gel, and W. Miao. 2009. The Impact of Levene's Test of Equality of Variances on Statistical Theory and Practice. Statistical Science 24: 343-360 https://doi.org/10.1214/09-STS301.

Hiers, J.K., J.J. O'Brien, R.J. Mitchell, J.M. Grego, and E.L. Loudermilk. 2009. The wildland fuel cell concept: an approach to characterize fine-scale variation in fuels and fire in frequently burned longleaf pine forests. International Journal of Wildland Fire 18: 315-325 https://doi.org/10.1071/WF08084.

Kane, J.M., J.M. Varner, and J.M. Hiers. 2008. The burning characteristics in southeastern oaks: discriminating fire facilitators from fire impeders. Forest Ecology and Management 256: 2039-2045 https://doi.org/10.1016/j.foreco. 2008.07.039.

Keyser, T.L., M. Arthur, and D.L. Loftis. 2017. Repeated burning alters the structure and composition of hardwood regeneration in oak-dominated forests of eastern Kentucky, USA. Forest Ecology and Management 393: 1-11 https://doi. org/10.1016/j.foreco.2017.03.015.

Kreye, J.K., J.M. Varner, and E.E. Knapp. 2012. Moisture desorption in mechanically masticated fuels: effects of particle fracturing and fuelbed compaction. International Journal of Wildland Fire 21: 894-904 https://doi.org/10.1071/ WF11077.

Kreye, J.K., J.M. Varner, J.K. Hiers, and J. Mola. 2013. Toward a mechanism for eastern North American forest mesophication: the role of litter drying. Ecological Applications 23: 1976-1986 https://doi.org/10.1890/13-0503.1.

Kreye, J.K., J.M. Varner, and C.J. Dugaw. 2014. Spatial and temporal variability of forest floor duff characteristics in long-unburned Pinus palustris forests. Canadian Journal of Forest Research 44: 1477-1486 https://doi.org/10.1139/ cjfr-2014-0223.

Kreye, J.K., J.K. Hiers, J.M. Varner, B. Hornsby, S. Drukker, and J.J. O'Brien. 2018a. Effects of solar exposure and litter position on forest floor moisture dynamics: influence of overstory structure and litter type. Canadian Journal of Forest Research 48: 1331-1342 https://doi.org/10.1139/cjfr-2018-0147.

Kreye, J.K., J.M. Varner, G. Hamby, and J.M. Kane. 2018b. Mesophytic litter dampens flammability in fire-excluded pyrophytic oak-hickory woodlands. Ecosphere 9: e02078 https://doi.org/10.1002/ecs2.2078.

Lee, R. 1978. Forest microclimatology. New York: Columbia University Press. Lenth, R.V. 2016. Least-squares means: The R package Ismeans. Journal of Statistical Software 69: 1-33 https://doi.org/10.18637/jss.v069.i01.

Loudermilk, L.E., W.P. Cropper, R.J. Mitchell, and H. Lee. 2011. Longleaf pine (Pinus palustris) and hardwood dynamics in a fire-maintained ecosystem: a simulation approach. Ecological Modeling 222: 2733-2750 https://doi.org/10. 1016/j.ecolmodel.2011.05.004.

Matthews, S. 2014. Dead fuel moisture research: 1991-2012. International Journal of Wildland Fire 23: 78-92 https://doi.org/10.1071/WF13005. 
Melvin M (2015) 2015 National prescribed fire survey report. Tech. Report 02-15. Coalition of Prescribed Fire Councils, Inc. (Newton, GA)

Miller, R.G., Jr. 1966. Simultaneous statistical inference. New York: McGraw-Hill. Mitchell, RJ., Hiers, J.K., O'Brien J., and G. Starr. 2009. Ecological forestry in the Southeast: understanding the ecology of fuels. Journal of Forestry. 107: 391-97.

Mola, J.M., J.M. Varner, E.S. Jules, and T. Spector. 2014. Altered community flammability in Florida's Apalachicola Ravines and implications for the persistence of the endangered conifer Torreya taxifolia. PLOS ONE 9: e103933 https://doi.org/10.1371/journal.pone.0103933.

Nelson, R.M., Jr. 2001. Water relations of forest fuels. In Forest Fires: Behavior and Ecological Effects, ed. E.A. Johnson and K. Miyanishi, 594. California: Academic Press https://doi.org/10.1016/B978-012386660-8/50006-4.

Nowacki, G.J., and M.D. Abrams. 2008. The demise of fire and "mesophication" of forests in the eastern United States. BioScience 58: 123-138 https://doi.org/10. 1641/B580207.

R Development Core Team (2018) R: A language and environment for statistical computing. R Foundation for Statistical Computing, Vienna, Austria.

Ray, D., D. Nepstad, and P. Moutinho. 2005. Micrometeorological and canopy controls of fire susceptibility in a forested Amazon landscape. Ecological Applications 15: 1664-1678 https://doi.org/10.1890/05-0404.

Rothermel, RC. 1972. A mathematical model for predicting fire spread in wildland fuels. USDA Forest Service Intermountain Forest and Range Experiment Station Research Paper INT-115. (Ogden UT).

Shapiro, S.S., and M.B. Wilk. 1965. An Analysis of Variance Test for Normality (Complete Samples). Biometrika 52: 591-611 https://doi.org/10.1093/biomet/ 52.3-4.591.

Simeoni, A., P. Salinesi, and F. Morandini. 2011. Physical modelling of forest fire spreading through heterogeneous fuel beds. International Journal of Wildland Fire 20: 625-632 https://doi.org/10.1071/WF09006.

Tanskanen, H., A. Granstrom, A. Venalainen, and P. Puttonen. 2006. Moisture dynamics of moss-dominated surface fuel in relation to the structure of Picea abies and Pinus sylvestris stands. Forest Ecology and Management 226: 189-198 https://doi.org/10.1016/j.foreco.2006.01.048.

Van Wagner, C.E. 1969. Drying rates of some fine forest fuels. Fire Control Notes 30: 1-4.

Varner, J.M., J.M. Kane, J.K. Kreye, and E. Engber. 2015. The flammability of forest and woodland litter: A synthesis. Current Forestry Reports 1: $91-99$ https://doi. org/10.1007/s40725-015-0012-x.

Viney, N.R. 1991. A review of fine fuel moisture modelling. International Journal of Wildland Fire 1: 215-234 https://doi.org/10.1071/WF9910215.

\section{Publisher's Note}

Springer Nature remains neutral with regard to jurisdictional claims in published maps and institutional affiliations.

\section{Submit your manuscript to a SpringerOpen ${ }^{\circ}$ journal and benefit from:}

- Convenient online submission

- Rigorous peer review

- Open access: articles freely available online

- High visibility within the field

- Retaining the copyright to your article

Submit your next manuscript at $\boldsymbol{\nabla}$ springeropen.com 